\title{
HEAT RECOVERY SYSTEM IN AN INDUSTRIAL FURNACE TO GENERATE AIR CONDITIONING THROUGH AN ABSORPTION CHILLER
}

Juan Pablo Vargas Bautista

\begin{abstract}
A case study of a Heat Recovery System is performed in an industrial furnace that uses natural gas to determine the absorption cooling capacity ( $\mathrm{LiBr}-$ Water) that can be generated for air conditioning. The energy source will be the heat of the flue gas that is eliminated by the furnace stack. Thermodynamic and economic analysis of the entire system (heat recovery exchanger, absorption chiller, cooling tower, etc.) is performed. A methodology to evaluate the Heat Recovery potential of the industrial furnace will be shown, as well as the limitations that must be considered. This methodology also considers the favorable environmental impact that is available to perform a heat recovery project. The results show that under certain operational characteristics and conditions, the heat recovery system is technically and economically feasible (profitable).
\end{abstract}

Keywords: Heat Recovery, Absorption Chiller, Air Conditioning, Energy Savings. 